\title{
STUDI KEBERHASILAN PENGELOLAAN WISATA BERBASIS COMMUNITY BASED TOURISM (STUDI KASUS: AIR TERJUN TUMPAK SEWU, DESA SIDOMULYO, KECAMATAN PRONOJIWO, KABUPATEN LUMAJANG)
}

\author{
Farrisha Haidir ${ }^{1)}$, Parino Rahardjo ${ }^{2)}$, Suryono Herlambang ${ }^{3)}$ \\ 1)Program Studi S1 PWK, Fakultas Teknik, Universitas Tarumanagara, farrisha.345170015@stu.untar.ac.id \\ 2)Program Studi S1 PWK, Fakultas Teknik, Universitas Tarumanagara, parinor@ft.untar.ac.id \\ 3)Program Studi S1 PWK, Fakultas Teknik, Universitas Tarumanagara, suryonoh@ft.untar.ac.id
}

Masuk: 29-07-2021, revisi: 03-09-2021, diterima untuk diterbitkan: 23-10-2021

\begin{abstract}
Abstrak
Indonesia merupakan negara yang memiliki kekayaan alam yang tak terbatas dan berpotensi sebagai sektor pariwisata. Pariwisata saat ini menjadi sektor yang berpotensi untuk dikembangkan sebagai sumber yang dapat mendorong laju pertumbuhan ekonomi bagi Negara. Selain itu, berkembangnya objek wisata yang ada di setiap daerah, diharapkan juga dapat meningkatkan perekonomian bagi masyarakat di sekitarnya. Wisata Air Terjun Tumpak Sewu yang berlokasi di Kabupaten Lumajang adalah salah satu objek wisata yang dikelola oleh masyarakat Desa Sidomulyo menggunakan konsep Community Based Tourism (CBT). Konsep CBT merupakan cara dalam menciptakan pariwisata yang berkelanjutan, dimana konsep ini membutuhkan partisipasi masyarakat lokal dalam mengembangkan dan juga mengelola objek wisata hingga berhasil. Dalam pengelolaan objek wisata Air Terjun Tumpak Sewu belum diketahui faktor - faktor yang menentukan keberhasilannya. Oleh karena itu, tujuan dari penelitian ini adalah untuk mengetahui sistem pengelolaan wisata, mengetahui peran masyarakat dalam mengelola wisata, dan mengetahui faktor-faktor keberhasilan pengelolaan objek wisata. Penelitian ini merupakan penelitian deskriptif dengan pendekatan kualitatif dan kuantitatif. Pengumpulan data kualitatif dikumpulkan dengan melakukan survey lapangan ke lokasi objek wisata dan wawancara mendalam (in- depth interview) dengan pihak - pihak yang terkait, sedangkan pengumpulan data kualitatif dilakukan dengan pengisian kuesioner oleh pengunjung. Hasil dari penelitian ini akan mendapatkan berupa faktor - faktor yang mempengaruhi keberhasilan dalam pengelolaan objek wisata Air Terjun Tumpak Sewu.
\end{abstract}

Kata kunci: Air Terjun Tumpak Sewu; Community Based Tourism (CBT); Keberhasilan; Pengelolaan

\begin{abstract}
Indonesia is a country that has unlimited natural wealth and potential as a tourism sector. Tourism is currently a sector that has the potential to be developed as a source that can encourage the rate of economic growth for the country. In addition, the development of tourism objects in each region is also expected to increase the economy for the surrounding community. Tumpak Sewu Waterfall Tourism which is located in Lumajang Regency is one of the attractions managed by the people of Sidomulyo Village using the concept of Community Based Tourism (CBT). The CBT concept is a way of creating sustainable tourism, this concept requires the participation of local communities in developing and managing tourism objects to succeed. In the management of the Tumpak Sewu Waterfall tourist attraction, the factors that determine its success are not yet known. Therefore, the purpose of this research is to to find out the tourism management system, to know the role of the community in managing tourism, and to know the success factors of tourism object management. This research is a descriptive research with qualitative and quantitative approaches. Qualitative data collection was collected by conducting field surveys to tourist attraction locations and in-depth interviews with related parties, and qualitative data collection was carried out by filling out questionnaires by visitors. The results of this study will get in the form of factors that influence the success in managing the Tumpak Sewu Waterfall tourist attraction.
\end{abstract}

Keywords: Community Based Tourism (CBT); Management; Success; Tumpak Sewu Waterfall 


\section{PENDAHULUAN}

\section{Latar Belakang}

Air Terjun Tumpak Sewu berlokasi di Desa Sidomulyo, Kecamatan Pronojiwo, Kabupaten Lumajang, Jawa Timur. Air terjun ini merupakan salah satu objek wisata yang ada di Kabupaten Lumajang dan termasuk kedalam 10 destinasi wisata terpopular di Kabupaten Lumajang. Pengelolaan objek wisata ini berbasis komunitas atau disebut dengan community based tourism, yaitu pengelolaan yang berasal dari masyarakat dan hasilnya dapat dimanfaatkan untuk masyarakat. Masyarakat sekitar wisata Air Terjun Tumpak Sewu dapat dikatakan sudah cukup berhasil dalam mengelola dan mengembangkan potensi sumber daya alam maupun sumber daya manusia yang dimiliki, hal ini dikarenakan sudah berkurangnya tingkat pengangguran dan meningkatkanya kesejahteraan masyarakat sekitar. Berdasarkan wawancara dengan beberapa stakeholder yang terlibat dalam pengelolaan wisata, masyarakat Desa Sidomulyo dahulu banyak terdapat masyarakat yang tidak memiliki pekerjaan, selain itu masyarakat hanya bergantung pada mata pencahariannya sebagai petani salak dan juga dari segi pendidikan masih terbatas. menurut data profil Desa Sidomulyo, $46 \%$ masyarakat desa hanya lulusan sekolah dasar.

Sebelum adanya wisata Air Terjun Tumpak Sewu, lokasi ini merupakan tempat warga mencari rumput, kemudian salah satu warga desa yaitu Abdul Karim berinisiatif untuk menjadikan desa ini sebagai objek wisata dengan melihat dari berbagai sudut desa yang layak untuk dijadikan daya tarik wisata. Dengan mengajak masyarakat untuk ikut berpartisipasi dalam menjadikan desa sebagai objek wisata, pada akhirnya terpilihlah air terjun yang memiliki keunikan berupa aliran air terjun yang melebar seperti tirai dan air terjun ini dinamakan Air Terjun Tumpak Sewu dan diresmikan pada tanggal 13 Maret 2015. Selain itu pada tanggal tersebut juga sebagai peresmian Kelompok Sadar Wisata (Pokdarwis) Tumpak Sewu yang beranggotakan masyarakat desa.

Semenjak Air Terjun Tumpak Sewu dikelola sebagai objek wisata, menjadikan wisata ini sebagai lapangan pekerjaan baru dan banyak pemuda yang terlibat dalam pengelolaan wisata. Selain itu, setiap bulan terdapat 2.000 lebih wisatawan lokal dan 150-200 wisatawan asing yang berkujung. Pada tahun 2018, Wisata Air Terjun Tumpak Sewu meraih penghargaan juara pertama di Anugerah Wisata Jawa Timur 2018 dalam kategori daya tarik alam. Hal ini dikarenakan keindahan alam yang ada terjaga keindahannya karena pengelolaan wisatanya. Menurut Kabid Pemasaran Disparbud Lumajang, Arief Efendi, Pokdarwis Tumpak Sewu mampu mengelola dengan baik dan menggerakan masyarakat sekitar untuk ikut berpartisipasi, sehingga dampak positif dapat dirasakan warga dalam hal pendapatan dan juga ekonomi. Selain itu, menurut Ketua Pokdarwis Tumpak Sewu, pendapatan dari wisata ini mencapai puluhan hingga ratusan juta setiap bulannya. Hingga saat ini, jumlah pengunjung wisatawan mancanegara terus bertambah setiap tahunnya.

Pengelolaan wisata Air Terjun Tumpak Sewu yang mengandalkan partisipasi masyarakat sekitar, dapat dijadikan contoh untuk pengelolaan wisata lainnya. Oleh karena itu, penelitian ini bertujuan untuk mengetahui sistem pengelolaan wisata, mengetahui peran masyarakat dalam mengelola wisata, dan mengetahui faktor-faktor keberhasilan pengelolaan objek wisata.

\section{Rumusan Masalah}

Objek wisata Air Terjun Tumpak Sewu yang baru dikelola pada tahun 2015, saat ini sudah berkembang dan dikenal oleh masyarakat luas. Dengan banyaknya jumlah pengunjung, besarnya pendapatan yang diperoleh, dan keikutserataan masyarakat dalam mengelola wisata ini, menjadikan wisata Air Terjun Tumpak Sewu mendapatkan penghargaan pada Anugerah Wisata Jawa Timur 2018. Tetapi, belum banyak diketahui daya tarik dari Air Terjun Tumpak Sewu bagaimana sistem pengelolaan yang dimiliki Air Terjun Tumpak Sewu, bagaimana peran Pokdarwis dalam mengelola wisata, dan faktor - faktor apa saja yang mendukung keberhasilan pengelolaan wisata ini. 


\section{Tujuan}

Tujuan dari penelitian ini adalah untuk mengetahui sistem pengelolaan objek wisata Air Terjun Tumpak Sewu, mengetahui peran Pokdarwis dalam mengelola objek wisata Air Terjun Tumpak Sewu, dan mengetahui faktor - faktor apa saja yang mempengaruhi keberhasilan pengelolaan objek wisata Air Terjun Tumpak Sewu.

\section{KAJIAN LITERATUR}

\section{Parwisata}

Menurut Oka A. Yoeti (1987) pada buku Pengantar Ilmu Pariwsata, pariwisata adalah suatu perjalanan yang dilakukan dalam sementara waktu dari suatu tempat ketempat lainnya dengan tujuan untuk menikmati perjalanan dalam memenuhi keinginan untuk bertamasya dan berekreasi bukan untuk bekerja.

\section{Community Based Tourism (CBT)}

Menurut Buku ASEAN Community Based Tourism Standart (2018) CBT merupakan kegiatan pariwisata yang dimiliki dan dioperasikan oleh masyarakat, dikelola atau dikoordinasikan di tingkat masyarakat yang berkontribusi pada kesejahteraan masyarakat dengan mendukung mata pencaharian yang berkelanjutan dan melindungi nilai tradisi sosial budaya dan juga sumber daya warisan alam dan budaya.

Dari definisi diatas, Community Based Tourism memiliki beberapa prinsip, prinsip-prinsip ini diintegrasikan dan dinyatakan sebagai kriteria kinerja dalam standar.

1) Melibatkan dan memberdayakan masyarakat untuk memastikan kepemilikan dan pengelolaan yang transparan.

2) Menjalin kemitraan dengan pemangku kepentingan yang terkait.

3) Mendapatkan kedudukan yang diakui dengan otoritas terkait.

4) Meningkatkan kesejahteraan sosial dan pemeliharaan martabat manusia.

5) Adanya mekanisme pembagian keuntungan yang adil dan transparan.

6) Meningkatkan ekonomi lokal dan regional.

7) Menghormati budaya dan tradisi lokal.

8) Berkontribusi pada konservasi sumber daya alam.

9) Meningkatkan kualitas pengalaman pengunjung dengan memperkuat interaksi antara tuan rumah dan pengunjung.

10) Bekerja menuju kemandirian finansial.

\section{Kelompok Sadar Wisata (Pokdarwis)}

Menurut Buku Pedoman Kelompok Sadar Wisata (2012), kelompok sadar wisata atau yang disebut dengan Pokdarwis merupakan lembaga di tingkat masyarakat yang anggotanya terdiri dari pelaku kepariwisataan yang memiliki kepedulian dan tanggung jawab serta berperan sebagai penggerak dalam mendukung terciptanya iklim kondusif bagi tumbuh dan berkembangnya kepariwisataan serta terwujudnya Sapta Pesona dalam meningkatkan pembangunan daerah melalui kepariwisataan dan manfaatnya bagi kesejahteraan masyarakat sekitar.

Dalam penyusunan Pedoman Kelompok Sadar Wisata, terdapat beberapa dasar hukum yang menjadi payung, yaitu:

- UU Nomor 10 Tahun 2009 tentang Kepariwisataan

- Instruksi Presiden Republik Indonesia Nomor 16 Tahun 2005 tentang Kebijakan Pembangunan Kebudayaan dan Pariwisata

- Peraturan Menteri Kebudayaan dan Pariwisata Nomor PM. 07/HK.001/MKP-2007 tentang Perubahan kedua atas Peraturan Menteri Kebudayaan dan Pariwisata Nomor PM.17/HK.001/MKP-2005 tentang Organisasi Pedoman Kelompok Sadar WIsata

- Peraturan Menteri Kebudayaan dan Pariwisata No. PM.04/PR.001/MKP/08 tentang Sadar Wisata 
- Peraturan Menteri Kebudayaan dan Pariwisata no.11 PM 17/PR.001/MKP/2010 tentang Rencana Strategis Kementrian Kebudayaan dan Pariwisata Tahun 2010-2014

\section{METODE}

Pada penelitian ini menggunakan pendekatan kualitatif dan kuantitatif. Dalam pendekatan kualitatif bertujuan untuk mengetahui mengenai sistem pengelolaan wisata Air Terjun Tumpak Sewu dan pendekatan kuantitatif bertujuan untuk mengetahui persepsi dan preferensi pengunjung terhadap wisata Air Terjun Tumpak Sewu.

Populasi (N) merupakan jumlah pengunjung objek wisata Air Terjun Tumpak Sewu pada tahun 2019 berdasarkan data dari Dinas Pariwisata dan Kebudayaan Kabupaten Lumajang, yaitu sebanyak 39.819 pengunjung dengan tingkat kesalahan dalam pengambilan sampel $10 \%$. Dalam penelitian ini menggunakan perhitungan sample menurut Rumus Solvin (Sugiyono, 2011:37), maka diperoleh perhitungan jumlah sampel sebagai berikut:

$$
\begin{gathered}
39.819 \\
n=1+(39.819 \times 0.12) \\
n=99,75 \approx 100
\end{gathered}
$$

Berdasarkan perhitungan sampel diatas, maka didapatkan jumlah sampel sebanyak 99,75 orang atau dibulatkan menjadi 100 orang.

\section{DISKUSI DAN HASIL}

\section{Analisis Lokasi}

Untuk menuju ke lokasi objek studi dapat di akses melalui jalur darat dengan kendaraan pribadi maupun transportasi umum, baik dari arah Kota Lumajang, Kabupaten Jember, dan juga Kabupaten

\begin{tabular}{|c|c|c|c|}
\hline Lokasi Asal & Rute & $\begin{array}{l}\text { Jarak Tempuh } \\
\qquad(\mathrm{Km})\end{array}$ & $\begin{array}{l}\text { Waktu } \\
\text { Tempuh }\end{array}$ \\
\hline Pusat Kota & JI. Raya Malang-Gempol - Jl. S Supriadi - Jl. Raya Genengan & & \\
\hline Malang & $\begin{array}{l}\text { - Jl. Raya Pakisaji - Jl. Raya Pepen - Jl. Raya Panglima } \\
\text { Sudirman - Jl. Ahmad Yani - Jl. Nasional }\end{array}$ & 75 & $2.5 \mathrm{jam}$ \\
\hline $\begin{array}{l}\text { Pusat Kota } \\
\text { Lumajang }\end{array}$ & $\begin{array}{l}\text { Jl. Brigjend Slamet Riyadi - Jl. Letkol Slamet Wardoyo - JI. } \\
\text { Raya Labruk Kidul - Jl. Raya Sumbersuko - Jl. Raya Tempeh } \\
\text { - Jl. Raya Pasirian - Jl. Raya Dampit-Lumajang }\end{array}$ & 55 & $1.5 \mathrm{jam}$ \\
\hline $\begin{array}{l}\text { Pusat Kota } \\
\text { Jember }\end{array}$ & $\begin{array}{l}\text { Jl. Gajah Mada - Jl. Brawijaya - Jl. Dharmawangsa - Jl. Raya } \\
\text { Lumajang-Jember - Jl. Brigjend Slamet Riyadi - JI. Letkol } \\
\text { Slamet Wardoyo - Jl. Raya Labruk Kidul - Jl. Raya } \\
\text { Sumbersuko - Jl. Raya Tempeh - Jl. Raya Pasirian - Jl. Raya } \\
\text { Dampit-Lumajang }\end{array}$ & 124 & 3 jam \\
\hline
\end{tabular}
Malang melalui Jalan Nasional III.

Tabel 1. Akses Menuju Wisata Air Terjun Tumpak Sewu

Sumber: Penulis, 2021

\section{Analisis Daya Tarik}

What to see

Objek wisata Air Terjun Tumpak Sewu memiliki daya tarik wisata berupa aliran air yang melebar seperti tirai dan mengingatkan pada Niagara Waterfall. Air terjun ini memiliki ketinggian sekitar 120 m. Air terjun ini merupakan air terjun yang terbentuk di aliran Sungai Glidih yang berhulu di Gunung Semeru. Popularitas Air Terjun Tumpak Sewu dikenal sebagai Niagara Jawa Timur. 

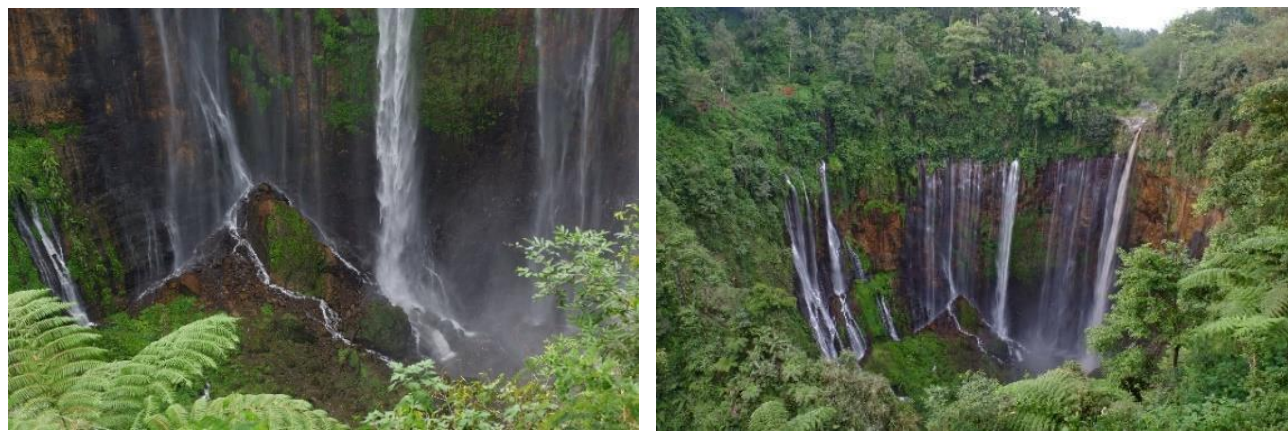

Gambar 1. Panorama Air Terjun Tumpak Sewu

Sumber: Penulis, 2020

\section{What to do}

Pada objek wisata Air Terjun Tumpak Sewu, pengelola objek wisata menyediakan beberapa kegiatan yang dapat dilakukan pengunjung di objek wisata Air Terjun Tumpak Sewu, seperti menyediakan spot untuk berfoto, melakukan trekking menuju ke dasar air terjun, dan memetik buah salak.

\section{What to buy}

Objek wisata Air Terjun Tumpak Sewu hanya memiliki dua tempat yang menjual barang- barang souvenir dan juga hasil kerajinan tangan masyarakat desa setempat. Barang-barang yang diperjual belikan pun masih sedikit hanya kaos-kaos dan tas hasil dari barang bekas. Selain itu, juga terdapat warung makan yang menjual makanan berat dan makanan ringan, tetapi tidak banyak warung makan yang menyajikan makanan khas daerah setempat.

\section{What to stay}

Pada objek wisata Air Terjun Tumpak Sewu terdapat tujuh homestay yang disediakan. Rata- rata biaya untuk menginap permalamnya yaitu sekitar $100.000-250.000$, tergantung dari fasilitas yang disediakan pemilik rumah.

\section{What to arrived}

Untuk menuju ke wisata Air Terjun Tumpak Sewu dapat di akses melalui jalur darat dengan kendaraan pribadi maupun transportasi umum, baik dari arah Kota Lumajang, Kabupaten Jember, dan juga Kabupaten Malang melalui Jalan Nasional III.

\section{Analisis Organisasi}

\section{Organisasi di Wisata Air Terjun Tumpak Sewu}

Pada objek wisata Air Terjun Tumpak Sewu terdapat sebuah organisasi yang bertugas sebagai pelopor pengembangan objek wisata Tumpak Sewu dan merupakan pengelola utama dari objek wisata ini, organisasi tersebut yaitu berbernama kelompok sadar wisata atau Pokdarwis Tumpak Sewu. Pokdarwis Tumpak Sewu berkedudukan di Desa Sidomulyo dan kelompok ini beranggotakan masayarakat Desa Sidomulyo yang memiliki bertujuan sebagai penggerak dalam mendukung terciptanya iklim kondusif bagi tumbuh dan berkembangnya kepariwisataan serta terwujudnya Sapta Pesona dalam meningkatkan pembangunan daerah melalui kepariwisataan dan manfaatnya bagi kesejahteraan masyarakat. Pokdarwis Tumpak Sewu diresmikan pada tanggal 13 maret 2015 sekaligus peresmian wisata Air Terjun Tumpak Sewu. Berikut ini akan dijelaskan tentang dasar hukum yang dimiliki pokdarwis, sejarah dari pokdarwis, kepengurusan yang ada pada struktur organisasi, dan kegiatan yang dilakukan pokdarwis.

Pada kepengurusan Pokdarwis Tumpak Sewu kelompok ini beranggotakan masyarakat Desa Sidomulyo dengan jumlah anggota aktif yaitu 25 orang. Anggota Pokdarwis Tumpak Sewu terdiri dari masyarakat desa yang tidak memiliki pekerjaan dan juga ada beberapa yang dulunya sebagai buruh 
tani. Awal pembentukan pokdarwis ini memiliki tujuan untuk menjadikan tempat tinggal mereka sebagai destinasi wisata dan berharap dapat meningkatkan kesejahteraan masyarakat guna memiliki penghasilan yang mandiri. Dalam stuktur kepengurusan Pokdarwis Tumpak Sewu memiliki seorang ketua, wakil ketua, bedahara, sekretaris, 2 orang bendahara, 5 orang yang terbagi dibeberapa devisi, dan 15 anggota.

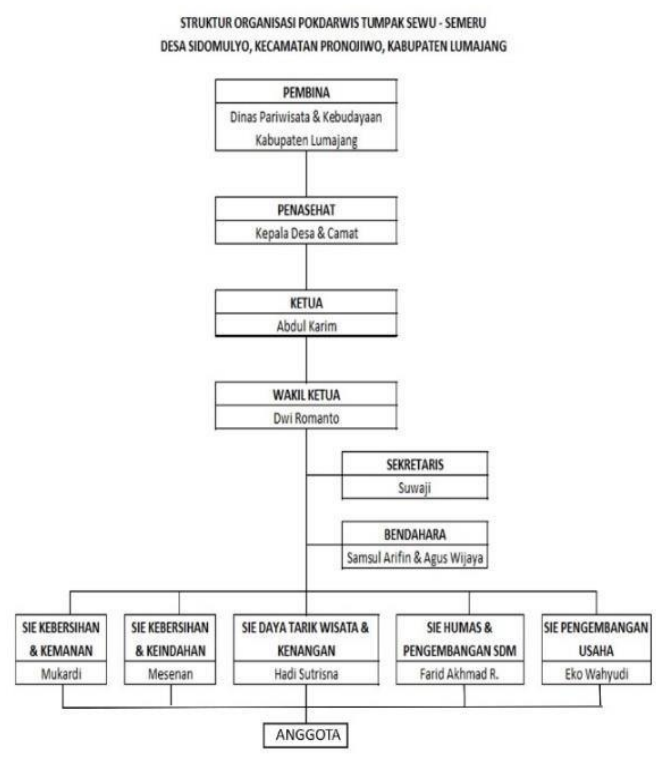

Gambar 2. Struktur Organisasi Pokdarwis Tumpak Sewu Sumber: Pokdarwis Tumpak Sewu

Berikut ini merupakan kegiatan Pokdarwis Tumpak Sewu:

- Kegiatan utama dari pokdarwis yaitu mengelola wisata seperti parkir, tiket masuk, dan pendapatan wisata.

- Memberikan edukasi pada masyarakat dalam hal kepariwisataan.

- Mengedukasi masyarakat sekitar untuk menerapkan dan meningkatkan kualitas lingkungan dan daya tarik.

- Memberikan pelatihan mandiri kepada tourguide dan pemilik homestay.

- Memberikan arahan kepada masyarakat untuk menjadi tuan rumah yang baik.

- Mempromosikan wisata Air Terjun Tumpak Sewu.

- Membuat kegiatan yang dapat mempererat hubungan antar masyarakat.

\section{Analisis Pengelolaan Berbasis Community Based Tourism}

Dalam CBT terdapat prinsip pengelolaan yang diintegrasikan dan dinyatakan sebagai kriteria kinerja dalam standar pengelolaan. Berikut ini merupakan uraian mengenai kondisi eksisting pada objek wisata Air Terjun Tumpak Sewu dengan standar pendekatan berbasis Community Based Tourism (ASEAN Community Based Tourism Standart:2018).

1. Melibatkan dan memberdayakan masyarakat untuk memastikan kepemilikan dan pengelolaan yang transparan.

Pada objek wisata Air Terjun Tumpak Sewu, terdapat keterlibatan masyarakat lokal, dimana masyarakat lokal menjadi bagian dari Pokdarwis dan juga sebagai pelaku kepariwisataan lainnya. Masyarakat Desa Sidomulyo khususnya Dusun Krajan, ikut terlibat dalam mengembangkan objek wisata Air Terjun Tumpak Sewu, mulai dari tahap perencanaan, pembentukan organisasi Pokdarwis, pengelolaan kegiatan wisata, dan juga melibatkan masyarakat di luar pengelolaan wisata Air Terjun Tumpak Sewu. 
Keterlibatan masyarakat dalam pengelolaan wisata Air Terjun Tumpak Sewu pada tahap perencanaan, bermula dari adanya seorang warga yang peduli akan kesejahteraan masyarakat sekitar, setelah itu Beliau mengajak pemuda desa untuk menjadikan desa sebagai kawasan pariwisata dilihat dari potensi wisata yang ada di Desa Sidomulyo. Dari beberapa orang tersebut kemudian melakukan musyawarah kepada warga lainnya dengan menjelaskan manfaat apa saja yang akan didapat dengan adanya wisata tersebut. Setelah beberapa kali memberikan pengarahan, akhirnya warga desa setuju untuk mengembangkan desa sebagai kawasan pariwisata.

Dengan adanya dukungan masyarakat desa, kemudian pemuda desa membentuk kelompok sadar wisata (Pokdarwis) yang bertujuan untuk mengatur jalannya pengelolaan objek wisata Air Terjun Tumpak Sewu. Keikutsertaan masyarakat desa pada setiap aspek pengelolaan pariwisata yaitu seperti dengan mengadakan musyawarah atau rapat bulanan sebagai tempat dalam memberikan masukan atau pendapat dalam pengelolaan wisata dan mengevaluasi kegiatan kepariwisataan agar lebih baik kedepannya.

Pengelolaan wisata Air Terjun Tumpak Sewu juga memberdayakan masyarakat sekitar, baik yang bekerja sebagai pengelola maupun masyarakat yang diberdayakan sebagai pelaku usaha dengan cara membuka usaha warung makan, pengrajin souvenir, tukang ojek, tourguide, dan penyedia homestay. Selain itu juga pihak Pokdarwis dan juga pemerintah setempat memberikan pelatihan tentang homestay yang dijadikan tempat menginap bagi pengunjung dan juga pelatihan tourguide sebagai pelaku utama yang berinteraksi langsung dengan pengunjung. Dengan adanya kesempatan masyarakat dalam berusaha dan memberikan keterampilan tersebut, hal ini meningkatkan keadaan ekonomi serta kesejahteraan masyarakat desa dari usaha kepariwisataan, selain itu juga meningkatkan pengetahuan dan keterampilan masyarakat desa.

2. Menjalin kemitraan dengan pemangku kepentingan terkait.

Pengelolaan objek wisata Air Terjun Tumpak Sewu tidak lepas dari dukungan pemangku kepentingan yang terkait. Seperti adanya dukungan pemerintah daerah dan komunitas - komunitas yang ada.

"Dari pemerintah ada untuk bikin gapura pintu masuk itu, loket, terus ada sebagian bikin view point di panorama itu. Selain itu ada CSR dari Bank Indonesia itu yang bikin toilet diparkiran baru sebelah itu. Ada banyak dari komunitas-komunitas, komunitas motor, komunitas pecinta alam, dan bantuan kita dari seperti itu."

Dengan menjalin hubungan dengan pemangku kepentingan terkait, banyak bantuan yang didapatkan dalam pengembangan wisata Air Terjun Tumpak Sewu seperti adanya bantuan dengan cara memperbaiki aksesibilitas menuju desa, membuat gapura sebagai pintu masuk wisata, membangun loket, dan membangun view point di panorama. Selain itu juga memberikan pelatihan tourguide dan homestay yang diadakan secara rutin setiap tahunnya. Selain dari pemerintah daerah setempat, ada juga dukungan dari pemangku kepentingan lain, seperti, Corporate Social Responsibility (CSR) dari bank Indonesia, dengan bantuan membangun toilet. Ada juga bantuan dari komunitaskomunitas seperti, komunitas motor, komunitas pecinta alam untuk pengembangan wisata ini. Selain itu juga membangun kemitraan dengan universitas dengan mengadakan pelatihan bahasa asing untuk masyrakat desa.

3. Mendapatkan kedudukan yang diakui dengan otoritas terkait.

Keberadaan objek wisata Air Terjun Tumpak Sewu diakui dengan adanya Peraturan atau Surat Keputusan (SK) yang mendukung kedudukan objek wisata Air Terjun Tumpak Sewu. Berikut ini merupakan Peraturan dan Surat Keputusan yang mendukung pengembangan dan pengelolaan objek wisata Air Terjun Tumpak Sewu: 
- Peraturan Daerah Kabupaten Lumajang tentang Rencana Induk Pembangunan Kepariwisataan Kabupaten Lumajang Tahun 2018 - 2033. Berdasarkan perda tersebut, menyatakan bahwa Kecamatan Pronojiwo dan sekitarnya merupakan Destinasi Pariwisata Kabupaten (DPK) dan Desa Sidomulyo dan sekitarnya merupakan Kawasan Strategis Pariwisata Kabupaten (KSPK).

- Surat Keputusan Kepala Desa Sidomulyo tentang Pokdarwis Desa Wisata Tumpak Sewu Desa Sidomulyo Kecamatan Pronojiwo Kabupaten Lumajang. Berdasarkan keputusan tersebut, mengatur tentang pembaharuan struktur organisasi Pokdarwis Desa Wisata Tumpak Sewu Desa Sidomulyo Kecamatan Pronojiwo pada hari kamis tanggal 27 September 2018.

- Anggaran Dasar dan Anggaran Rumah Tangga Pokdarwis Tumpak Sewu. Dalam AD/ART Pokdarwis Tumpak Sewu menyatakan tentang tujuan dan kegiatan adanya perkumpulan Pokdarwis Tumpak Sewu, tugas dan wewenang dari struktur organisasi yang sudah ditentukan, kewajiban dan hak dari anggota, tata tertib bagi anggota, masyarkat sekitar dan pengunjung wisata.

4. Meningkatkan kesejahteraan sosial dan pemeliharaan martabat manusia.

Dengan adanya wisata Air Terjun Tumpak Sewu juga memberikan manfaat bagi masyarakat sekitar dalam aspek sosial. Kegiatan kepariwisataan yang ada memberikan dampak positif seperti berkurangnya tingkat pengangguran, hal ini dikarenakan kegiatan kepariwisataan yang ada membuka lapangan pekerjaan, seperti menjadi tourguide, ojek, dan juga banyak terdapat tempat penginapan, dan itu semua merupakan salah satu pendapatan bagi warga sekita wisata.

"Benar-benar terasah nggeh, pertama lapangan pekerjaan semakin terbuka, terus kemudian di pariwisata sendiri ada 2,5\% kita sisihkan untuk dana sosial, itu dari masing-masing destinasi, belum lagi setelah kita serahkan di BUMDes, dana tersebut kita alokasikan untuk masyarakat yatim piatu, duafa, dan rumah tangga miskin. Tidak hanya kita berbicara pariwisata nggeh, tidak hanya pariwisata yang income untuk desa, semua roda perekonomian masyarakat baik dari yang pertanian, perdagangan itu semuanya ikut andil."

Dari hasil wawancara dengan Sekretaris Desa Sidomulyo yaitu Bapak Syaiful, dapat dilihat bahwa pariwisata yang ada di Desa Sidomulyo juga memberikan dampak positif bagi kesejahteraan masyarakat sekitar yaitu seperti terbukanya lapangan pekerjaan dan juga adanya bantuan dana untuk masyarakat tertentu.

5. Adanya mekanisme pembagian keuntungan yang adil dan transparan.

Pendapatan objek wisata Air Terjun Tumpak Sewu secara keseluruhan berasal dari beberapa sumber, yaitu tiket masuk dan tiket parkir, kontribusi pedagang, kontribusi ojek, kontribusi tourguide, dan kontribusi homestay. Semua sumber pendapatan yang ada masuk ke dalam kas pengelola.

Pendapatan dari wisata Air Terjun Tumpak Sewu dari beberapa sumber tidak sepenuhnya digunakan untuk pengelolaan maupun pengembangan wisata, akan tetapi pendapatan yang ada masih dibagi lagi untuk keperluan lainnya. Pendistribusian hasil pun merupakan hasil dari musyawarah masyarakat yang terlibat dalam kegiatan kepariwisataan.

Persentase pendistribusisan pendapatan terbesar yaitu sebesar $57,5 \%$ yang digunakan untuk pengembangan infrastruktur dan juga gaji karyawan pengelola wisata. Lalu sebesar $20 \%$ merupakan pajak parkir dan retribusi daerah (PPRD). Setelah itu sebesar $15 \%$ digunakan untuk warga pemilik lahan yang digunakan, dibagi 20 orang dan dihitung permeter dari lahan yang digunakan. Selain itu pendistribusian pendapatan dengan masing- masing 2,5\% digunakan untuk dana sosial, kas lingkungan, dan juga untuk desa. 
6. Meningkatkan ekonomi lokal dan regional.

Keberadaan wisata Air Terjun Tumpak Sewu memberikan manfaat yang baik bagi masyarakat sekitarnya terutama dari segi ekonomi. Manfaat dari segi ekonomi yang timbul dari kegiatan kepariwisataan yaitu adanya pengingkatan pendapatan masyarakat sekitar, seperti membuka usaha warung, menjadikan rumahnya sebagai tempat penginapan, dan juga banyak warga yang bekerja sebagai tukang ojek, tourguide, dan porter.

"Dampaknya si multiplier effect, terutama diekonominya kan sangat ini sekali, apa yang namanya yang dulunya cuman apa ya disini tuh istilahnya rata-rata buruh tani, buruh lepas kaya gitu-gitu kan. Sekarang sudah mandiri lah istilahnya, sudah bisa mencari ekonomi, tidak tergantung orang lain. Contohnya kaya bikin warung, terus ada kamar kosong satu dua dirumahnya dijadikan homestay, bikin toilet, bisa ngojek, bisa jadi porter, jadi guide, banyak sekali sudah sekarang perbedaannya sama dulu."

Hal tersebut menunjukkan bahwa dengan adanya kegiatan kepariwisataan memberikan dampak positif bagi perekonomian masyarakat sekitarnya. Masyarakat desa turut berperan sebagai pelaku kepariwisataan dan manfaat adanya wisata dirasakan oleh masyarakatnya.

7. Menghormati budaya dan tradisi lokal.

Keberadaan wisata Air Terjun Tumpak Sewu juga menimbulkan kegiatan yang dapat melesatrikan kebudayaan dan tradisi lokal yang ada. Kegiatan tersebut dapat dilihat dengan adanya beberapa kegiatan pelestarian budaya seperti, penampilan kesenian pencak silat, jaranan, dan campursari. Selain itu juga adanya kegiatan membatik yang diajarkan oleh masyarakat sekitar kepada pengunjung, akan tetapi kegiatan ini tidak dijalankan lagi sejak adanya pandemi Covid-19.

"Ada seni budaya juga disini, kaya jaranan, pencak silat, campur sari, ada pertunjukannya sendiri kalau pas ada rombongan besar yang sekiranya cukup budgetnya untuk menyewa teman-teman seni ini."

Selain itu, masyarakat sekitar juga menerima adanya budaya dari luar, awalnya masyarakat kaget dengan budaya luar yang dibawa oleh pengunjung wisata, akan tetapi lama kelamanaan masyarakat bisa menerima dan tidak terpengaruh dengan adanya budaya luar. Hal ini dikarena pihak Pokdarwis sudah memberikan edukasi kepada masyarakat desa.

\footnotetext{
"Awalnya memang masyarakat kaget adanya budaya dari luar, tetapi terus masyarakay bisa menerima dan tidak terpengaruh dengan budaya luar, karena sudah kita edukasi dulu temanteman dan masyarakat itu. Selain itu kita juga mengenalkan adatnya kita seperti apa, kita utarakan juga kepada mereka."
}

Dari beberapa hal yang sudah disebutkan, dapat dilihat bahwa dengan adanya kegiatan wisata memberikan dampak yang baik bagi budaya dan tradisi yang ada, seperti menampilkan kegiatan pelestarian kebudayaan lokal kepada pengunjung dan juga masyarakat desa sangat terbuka serta menerima adanya budaya luar yang masuk. Hal ini memperlihatkan masyarkat desa saling menghormati budaya dan tradisi lokal maupun luar.

8. Berkontribusi pada konservasi sumber daya alam.

Kegiatan wisata Air Terjun Tumpak Sewu menjadikan masyarakat lebih menjaga potensi alam dan juga kondisi lingkungan sekitarnya. Masyarakat lebih berhati-hati mengenai potensi alam yang perlu dikembangkan dan diperkenalkan sebagai daya tarik wisata. Selain itu masyarakat juga menjaga kebersihan lingkungan sekitar dengan kegiatan membersihkan desa secara rutin dan juga 
membersihkan spot-spot wisata setiap harinya. Lalu masyarakat juga menjaga lingkungan dengan mendaur ulang sampah plastik menjadi kerajinan tangan yang diperjualkan kepada pengunjung.

Hal tersebut dapat dilihat bahwa dengan adanya kegiatan wisata masyarakat semakin peduli terhadap kondisi alam dan juga kondisi lingkungan sekitarnya. Sehinga antara kegiatan wisata dan juga kondisi alam sekitar tetap terjaga kelestariannya.

9. Meningkatkan kualitas pengalaman pengunjung dengan memperkuat interaksi antara tuan rumah dan pengunjung.

Pada objek wisata Air Terjun Tumpak Sewu, pengelola objek wisata menyediakan beberapa kegiatan yang dapat dilakukan pengunjung di objek wisata Air Terjun Tumpak Sewu, seperti melakukan trekking menuju ke dasar air terjun, memetik buah salak, dan membatik. Kegiatan ini juga dapat memperkuat interaksi pengunjung dengan masyarakat sekitar.

"Tidak hanya ke panorama saja, kita juga banyak goa-goa dibawah, ada goa bidadari, goa tetes, goa lawo, goa gaji, terus ada tebing nirwana, ada telaga biru, bisa trekking kita disana dengan edukasi alam. Terus ada banyak salak, kita juga beri edukasi tentang salak, ada agrowisatanya."

Kegiatan utama yang memberikan pengalaman kepada pengunjung yaitu melakukan trekking ke dasar air terjun, kegiatan ini memberikan pengelaman menarik yang tidak dapat pegunjung rasakan ditempat wisata lainnya, seperti menuruni jalur setapak yang curam dan juga melewati aliran air terjun sepanjang jalur trekking. Kegiatan ini juga dapat memperkuat interaksi dengan tuan rumah, yaitu dengan tourguide yang mengarahkan jalan dan tempat spot foto yang bagus. Tourguide sendiri merupakan pelaku wisata yang langsung berinteraksi dengan pengunjung, dengan memberikan informasi seputar wisata tersebut.

10. Bekerja menuju kemandirian finansial.

Tujuan dikembangkannya wisata Air Terjun Tumpak Sewu yaitu untuk meningkatkan kesejahteraan masyarakat sekitar dan juga mengembangkan potensi desa. Pada tanggal 12 Oktober 2019, Gubernur Jawa Timur meresmikan Desa Sidomulyo sebagai "Dewi Cemara” atau Desa Wisata Cerdas Mandiri Sejahtera.

"Desa Cemara itu pencanangan dari Gubernur dari lbu Khofifah, kita dicanangkan menjadi desa yang cerdas yang mandiri dan sejahtera, karena kita benar-benar mandiri, mandiri dari pendanaan, pengelolaan, dan sebagainya."

Maksud dari nama tersebut ialah masyarakat desa yang mampu mengembangkan desa dengan mandiri dan memberikan dampak yang positif bagi kesejahteraan masyarakat desa setempat. Dinobatkan sebagai desa yang mandiri dikarenakan masyarakat mampu mengembangkan potensi desa dan meningkatkan kesejahteraan dan perekonomian masyarakatnya secara mandiri.

\section{Analisis Kebijakan}

Analisis ini bertujuan untuk mengetahui kebijakan-kebijakan yang mengatur terkait tentang wisata Air Terjun Tumpak Sewu dan juga organisasi yang terlibat, sebagai acuan dalam keberhasilan pengelolaanya. Terdapat kebijakan-kebijakan baik dari pemerintah maupun dari pihak desa terkait wisata Air Terjun Tumpak Sewu. Kebijakan terkait wisata Air Terjun Tumpak Sewu diatur dalam peraturan pemerintah Kabupaten Lumajang, yaitu sebagai berikut:

- Peraturan Daerah Kabupaten Lumajang tentang Rencana Induk Pembangunan Kepariwisataan Kabupaten Lumajang Tahun 2018 - 2033.

- Peraturan Bupati Nomor 79 Tahun 2014 tentang Destinasi Wisata Satu Kecamatan Satu Desa Wisata di Kabupaten Lumajang. 
- Surat Keputusan Kepala Desa Sidomulyo tentang Pokdarwis Desa Wisata Tumpak Sewu Desa Sidomulyo Kecamatan Pronojiwo Kabupaten Lumajang.

- Anggaran Dasar dan Anggaran Rumah Tangga Pokdarwis Tumpak Sewu.

Dari kebijakan-kebijakan pemerintah diatas yang membahas tentang wisata Air Terjun Tumpak Sewu, dapat disimpulkan bahwa objek wisata Air Terjun Tumpak Sewu merupakan objek wisata yang diakui oleh daerah setempat dan juga organisasi yang ada merupakan organisasi yang legal.

\section{Analisis Persepsi dan Preferensi Pengunjung}

Dalam analisis ini menggunakan diagram cartesius yang bertujuan untuk mengetahui letak masingmasing faktor pada kuadran berapa saja.

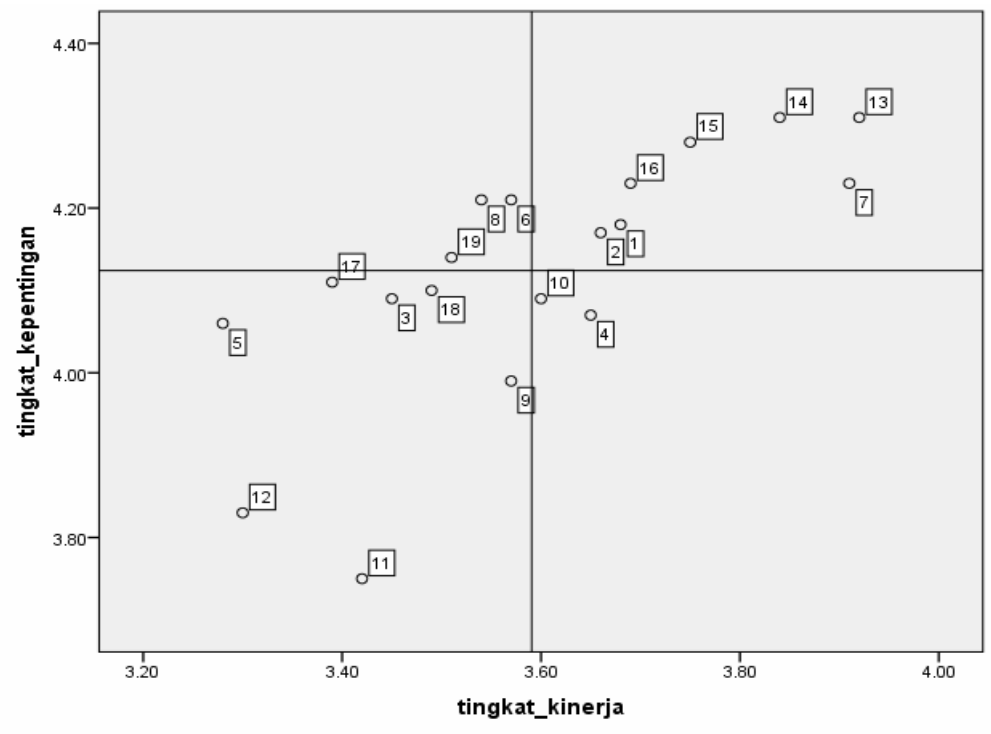

Gambar 3. Diagram Cartesius Kesesuaian Kinerja dan Kepentingan Sumber: Penulis, 2021

Berdasarkan hasil dari penyebaran kuesioner kepada pengunjung tentang kondisi dan kinerja atas semua aspek seperti aksesibilitas, infrastruktur, fasilitas, dan penerapan konsep CBT yang ada di wisata Air Terjun Tumpak Sewu dengan menggunakan diagram cartesius, didapatkan hasil bahwa yang terdapat pada kuadran I dianggap sebagai faktor yang penting, tetapi kondisi atau kinerja yang ada saat ini belum memuaskan, sehingga pihak pengelola perlu memprioritaskan faktor tersebut dalam meningkatkan kualitas pelayanan, yaitu kebersihan dan keamanan Kawasan, kebersihan toilet, dan kualitas akomodasi yang ada. Pada kuadran II dianggap sebagai faktor yang sangat penting dan pelayanan yang diberikan sudah memuaskan, yaitu akses menuju objek wisata, kondisi jalan, ketersediaan tempat parkir, keramahan dan kesopanan masyarakat lokal, keramahan dan kesopanan petugas, kualitas dan keahlian pemandu, dan kualitas tur dan aktivitas wisata. Pada kuadran III dianggap sebagai faktor yang memiliki tingkat kinerja yang rendah dan dianggap tidak terlalu penting bagi pengunjung, yaitu fasilitas penerangan, kualitas jaringan komunikasi, ketersediaan tempat makan, ketersediaan homestay, ketersediaan ruang kesehatan, kualitas rumah makan, dan kualitas makanan dan minuman. Pada kuadran IV dianggap sebagai faktor yang tidak terlalu penting tetapi pelayanan yang diberikan cukup memuaskan, yaitu rambu penunjuk arah dan ketersediaan mushola.

Berdasarkan kepuasan pengunjung terhadap wisata Air Terjun Tumpak Sewu dengan menggunakan metode CSI (Customer Satisfaction Index), didapatkan hasil sebesar 71,90 \% yang berarti bahwa responden yang merupakan sebagai sampel pengunjung objek wisata Air Terjun Tumpak Sewu 
merasa puas atas semua aspek seperti aksesibilitas, infrastruktur, fasilitas, dan penerapan konsep CBT.

Sedangkan berdasarkan preferensi pengunjung untuk kegiatan wisata yang perlu ditambahkan di wisata Air Terjun Tumpak Sewu yaitu wisata jembatan gantung dan kesenian daerah setempat, dan untuk fasilitas yang perlu ditambah yaitu penambahan outlet souvenir.

\section{Analisis Benchmark}

Dalam analisis benchmark ini, peneliti menggunakan objek wisata pembanding antara lain Tebing Breksi dan Umbul Ponggok. Dengan dasar kedua objek tersebut memiliki keunggulan seperti memiliki pemasukan yang besar, meningkatkan kesejahteraan lokal, jumlah pengunjung cendreung meningkat, laporan keuangan yang baik, dan mendapat penghargaan.

Dari data yang didapatkan, pengelolaan wisata pada ketiga objek wisata Air Terjun Tumpak Sewu, Tebing Breksi, dan Umbul Ponggok merupakan pengelolaan wisata yang berbasis masyarakat, yang memiliki tujuan untuk meningkatkan kesejahteraan masyarakat sekitar objek dan menjadikan masyarakat yang mandiri dalam secara finansial. Ketiga objek ini juga mendapatakan penghargaan atas keberhasilan dalam pengelolaannya. Selain itu, dari kedua objek pembanding yaitu Tebing Breksi dan Umbul Ponggok, kedua objek tersebut memiliki pendapatan yang mencapai miliaran rupiah dan terus meningkat disetiap tahunnya. Hal ini dikarenakan kedua objek wisata tersebut dikelola oleh BUMDes, dimana BUMDes tersebut mengelola asset-asset yang ada di desa dan mengoptimalkan dari pendapatan yang ada. Selain itu, kedua wisata tersebut memiliki aturan yang mengatur tentang pembagian dan hasil dari pendapatan yang ada.

Pada Desa Sidomulyo telah membentuk BUMDes pada tahun 2018 yang bernama BUMDes Sumber Makmur. Akan tetapi BUMDes Sumber Makmur belum ikut andil dalam pengelolaan wisata Air Terjun Tumpak Sewu maupun usaha lainnya, hal ini dikarenakan belum adanya aturan tentang pembagian dan hasil dari pendapatan asset-asset desa. Oleh karena itu, Pokdarwis Tumpak Sewu tidak mengikutsertakan BUMDes dalam pengelolaan wisata, hal ini dikarenakan tidak adanya peraturan yang jelas dan juga mereka beranggapan bahwa Pokdarwis Tumpak Sewu lebih dulu muncul sebelum adanya BUMDes. Sehingga tidak adanya transparansi antara Pokdarwis dengan Desa.

Dari penjelasan diatas, hal tersebut dapat menimbulkan konflik dimasa yang akan datang. Oleh karena itu, terdapat beberapa saran agar tidak terjadinya konflik, yaitu yang pertama dengan membuat Standar Operasional Prosedur (SOP) yang telah disepakati oleh pihak-pihak terkait. Dengan adanya SOP tersebut maka masing-masing pihak memiliki wewenang dan tanggung jawab dalam mengimplementasikan keputusan yang terdapat di dalam SOP. Kedua, adanya sistem trasnparansi, dalam hal ini masing-masing pihak wajib melaporkan atas kegiatan yang sudah dijalankan, sehingga tidak ada hal-hal yang ditutupi, dan jika terjadinya masalah, maka pihak lain dapat membantu dalam menyelesaikan masalah tersebut. Terakhir, adanya pembagian dah hasil dari pendapatan yang adil dan telah disepakati bersama.

\section{KESIMPULAN DAN SARAN}

\section{Kesimpulan}

Objek wisata Air Terjun Tumpak Sewu merupakan salah satu wisata yang dikelola oleh organisasi ditingkat masyarakat yaitu Pokdarwis. Pokdarwis Tumpak Sewu merupakan pengelola utama wisata Air Terjun Tumpak Sewu dan beranggotakan masyarakat Desa Sidomulyo yang memiliki tujuan sebagai penggerak dalam mendukung terciptanya iklim kondusif bagi tumbuh dan berkembangnya kepariwisataan serta terwujudnya Sapta Pesona dalam meningkatkan pembangunan daerah melalui kepariwisataan dan manfaatnya bagi kesejahteraan masyarakat. 
Pengelolaan wisata yang dilakukan pada objek wisata Air Terjun Tumpak Sewu sudah memenuhi aspek-aspek dari prinsip CBT, yaitu melibatkan dan memberdayakan masyarakat untuk memastikan kepemilikan dan pengelolaan yang transparan, menjalin kemitraan dengan pemangku kepentingan yang terkait, mendapatkan kedudukan yang diakui dengan otoritas terkait, meningkatkan kesejahteraan sosial dan pemeliharaan martabat manusia, adanya mekanisme pembagian keuntungan yang adil dan transparan, meningkatkan ekonomi lokal dan regional, menghormati budaya dan tradisi lokal, berkontribusi pada konservasi sumber daya alam, meningkatkan kualitas pengalaman pengunjung, dan bekerja menuju kemandirian finansial.

Dari hasil penyebaran kuesioner kepada pengunjung didapatkan hasil yang baik dan pengunjung merasa puas atas pengelolaan yang diterapkan pada wisata Air Terjun Tumpak Sewu, seperti akses yang baik, sarana dan prasarana yang baik, dan juga penerapan konsep CBT yang diterapkan oleh pengelola maupun masyarakat lokal. Kepuasan pengunjung tersebut mendapatkan nilai CSI (Customer Satisfaction Index) sebesar 71,90\%. Dengan hasil yang diperoleh, pengelola dapat mempertahankan kinerja yang sudah berjalan atau meningkatkan kinerja yang sudah ada agar lebih baik lagi.

Dari hasil perbandingan dengan dua objek wisata yang berhasil yaitu wisata Tebing Breksi dan Umbul Ponggok, wisata Air Terjun Tumpak Sewu memiliki tujuan yang sama yaitu untuk meningkatkan kesejahteraan masyarakat sekitar objek dan menjadikan masyarakat yang mandiri dalam secara finansial. Selain itu ketiga objek wisata ini sudah berhasil meningkatkan kesejahteraan masyarakat sekitarnya.

\section{Saran}

Dari analisis yang sudah dilakukan, peneliti memiliki beberapa saran bagi pengelolaan wisata Air Terjun Tumpak, yaitu:

- Memunculkan kembali aktivitas wisata yaitu seperti adanya kegiatan membatik dan membuat kerajinan tangan dengan mengikutsertakan pengunjung, sehingga interaksi antar pengunjung dan tuan rumah lebih kuat.

- Jalan menuju dasar air terjun diperbaiki agar lebih aman dan nyaman saat pengunjung ingin menuju dasar air terjun.

- Meningkatkan kebersihan dan keamanan kawasan, kebersihan dari toilet, dan juga kualitas akomodas yang ada.

- Menambah kegiatan wisata baru yaitu kesenian daerah setempat dan penambahan outlet souvenir.

- Mengikutsertakan organisasi desa seperti BUMDes untuk mengelola pendapatan wisata agar dapat mengoptimalkan pengelolaan pendapatan yang sudah ada dan memiliki laporan keuangan yang baik.

- Meningkatkan kualitas pengelolaan dengan konsep CBT agar menjadi objek wisata yang berkelanjutan

\section{REFERENSI}

ASEAN Community Based Tourism Standart. (2016). Jakarta: ASEAN Secretariat.

BUMDes Tirta Mandiri Kalten Pengelola Umbul Ponggok. (n.d.). Retrieved from https://desaklaten.com

Hazliansyah. (2017). Air Terjun Tumpak Sewu dan Peran Aktif Masyarakat Sidomulyo. Retrieved from https://republika.co.id

Kades ini Sukses Dongrak Pendapatan Desa dari 80 juta menjadi 147 Miliar/tahun. (n.d.). Retrieved from https://gunungmaskab.go.id

Maryani. (1991). Pengantar Geografi Pariwisata. Bandung: Jurusan Pendidikan Geografi FPIPS IKIP. 
(n.d.). Peraturan Menteri Dalam Negeri Nomor 33 Tahun 2009 tentang Pedoman Pengembangan Ekowisata di Daerah.

Purwanto, H. (2018). Air Terjun Tumpak Raih Anugerah Wisata Jatim 2018. Retrieved from http://m.beritajatim.com

Rahim, I. F. (2012). Panduan Pedoman Kelompok Sadar Wisata.

Soetarso, P., \& Mulyadin, R. M. (2013). Pengembangan Desa WIsata : Pengembangan UndangUndang Otonomi Daerah, 38.

Spillane, J. J. (1987). Pariwisata Indonesia : Sejarah dan Prospeknya. Yogyakarta: Kanisius. (n.d.). Undang - Undangn Nomor 10 Tahun 2009 tentang Kepariwisataan.

Yoeti, O. A. (1987). Pengantar Ilmu Pariwisata. Bandung : Angkasa. 